\title{
PRODUCTION OF MALTO-DEXTRIN FROM BROKEN RICE
}

\author{
Saikat Mazumder ${ }^{1}$, Debabrata Bera ${ }^{2}$ \\ ${ }^{1}$ M.tech student, ${ }^{2}$ Assistant Professor, Department of Food Technology, Techno India, West Bengal, India, \\ saikat.23.1989@gmail.com,beradebabrata@yahoo.co.in
}

\begin{abstract}
Malto-dextrin, the mixture of glucose, maltose and dextrin is used in food industry, as bulking agent, fat replacer, and for medical/nutritional purpose. It is generally produced from cane sugar, maize (starch) etc. by acid or enzymatic hydrolysis. But presently its production rate is not so high. Malto-dextrin production from broken rice, a waste, is very beneficial because of its low cost and availability.

In this paper, the objective of this study was to maximize the malto-dextrin production from rice starch by acid hydrolysis and also the effect of particle size on production of malto-dextrin. The rice starch was hydrolyzed by Hydrochloric acid (HCl). The range of the factors employed were particle mesh size, gelatinization pressure and time, saccharification time. The optimized gelatinization condition was 15 psig for 30 minutes. The optimized acid hydrolysis condition was $67^{\circ} \mathrm{C}$ for 30 minutes. The optimized particle size was 18 meshes both for raw and parboiled rice. Maximum yield was 90.434\% (before separation of proteins), and 94.43\% (after separation of proteins).
\end{abstract}

Keywords: malto-dextrin, rice starch, acid hydrolysis, particle mesh size $* * *$

\section{INTRODUCTION}

Malto-dextrin $\left(\mathrm{C}_{6} \mathrm{H}_{10} \mathrm{O}_{5}\right)_{\mathrm{n}} \cdot \mathrm{H}_{2} \mathrm{O}$ is a mixture of saccharides with a molecular weight between polysaccharides and oligosaccharides with DE lower than 20 (not sweet), which is available as white powders mostly or concentrated solution [1]. Its physical and functional properties such as sweetness, compressibility and viscosity vary depending upon the extent of starch hydrolysis, which is characterized by DE determination [2]. It is used in food industry, as bulking agent, fat replacer, medical/nutritional purpose etc.

Rice starch granules (with diameters of ca. $5 \mu \mathrm{m}$ ), consist of two $\alpha$-D glucose polymers: nearly linear amylose and highly branched amylopectin. Within starch granules, three different regions are distinguished, i.e. alternating amorphous (low electron density) and semi-crystalline growth rings (thickness 120-400 nm). The latter consist of crystalline (high electron density) and amorphous (low electron density) lamellae with a repeat distance of 9-11 nm (R.E. Cameron et al.). Crystalline lamellae result from double helix formation of amylopectin side chain chains which aggregate to form crystals, whereas amorphous lamellae mainly contain amorphous amylopectin branch points [3].

Gelatinization is the irreversible melting process of starch. It is an endothermic process, and the peak temperature at which starch absorbs heat is called gelatinization temperature (GT). It is important because it affects the texture of cooked rice and it is said to be related to the cooking time of rice. When starch granules are heated in excess water above the gelatinization temperature, the supramolecular order (crystallinity) and 9-11 $\mathrm{nm}$ repeat are lost. Apart from this phenomenon, water absorption and thus swelling of the granule and amylose leaching occur during gelatinization [4].

Acid hydrolysis is generally done by $6(\mathrm{~N}) \mathrm{HCl}$. Acid generally breaks down $\alpha(1 \rightarrow 4)$ and $\alpha(1 \rightarrow 6)$ linkages of amylose and amylopectin present in gelatinized starch and produces maltodextrin after saccharification.

Production of malto-dextrin from broken rice, a waste, is very beneficial because of its low cost and availability in India as well as in West Bengal. In this study gelatinization of rice flour is the function of pressure, time and particle size and type and composition of starch and saccharification as a function of time. The parameters were optimized in this study.

\section{MATERIAL AND METHOD}

\subsection{Material}

\section{Preparation of Raw Material}

Both broken raw and parboiled rice were collected from local market of Kolkata. The rice samples were grinded in a ball mill and grinded samples were separated by a sieve shaker on the basis of their particle size. Rice flour with particle size of $18,30,44,60$ mesh was used for farther experiments except raw material study in which samples before grinding and 
sieving was used. The chemicals used in these study, were obtained from the Merck India Ltd.

\subsection{Methods}

\subsubsection{Proximate Composition Analysis}

Moisture, fat, ash, protein and amylose content were determined.

Moisture was determined gravimetrically in hot air oven at $130^{\circ} \mathrm{C}$ for $2 \mathrm{hrs}$. and then to constant weight. Determination of fat by solvent (n-hexane) extraction, ash by ashing method at $550^{\circ} \mathrm{C}$ for $5 \mathrm{hrs}$, protein by digestion and distillation (Kjeldahl) method and amylose content by spectrophotometric method as described by Sadasivam \& Manickam, 2005[5].

\subsubsection{Optimization of Gelatinization Process}

Gelatinization was carried out at 10 psig for 10 minutes, at 15 psig for 30 minutes and at 15 psig for 45 minutes and saccharification time (20 minutes) temperature $\left(67^{\circ} \mathrm{C}\right)$ was constant.

$5 \mathrm{gm}$ of sample from each of four mesh size (18, 30, 44 and 60 ) of raw and parboiled rice was taken in different conical flasks and followed by gelatinization at 10 psig 10 minutes, at 15 psig for 30 and at 15 psig for 45 minutes. Afterward $40 \mathrm{ml}$ $6(\mathrm{~N}) \mathrm{HCl}$ was added in each of the flasks and placed in a water bath at $67^{\circ} \mathrm{C}$ for 20 minutes for inversion and followed by neutralization of $\mathrm{pH}$ by sodium hydroxide solution $(40 \%$ w/v) volume was made up to $200 \mathrm{ml}$ in each of conical flasks. Then the samples were taken for assay of malto-dextrin.

\subsubsection{Optimization of Saccharification Process}

From the optimized gelatinization time-temperature profile 15 psig 30 minutes saccharification time was varied at 20, 30 and 45 minutes at $67^{\circ} \mathrm{C}$.

$5 \mathrm{gm}$ sample from each of four mesh size $(18,30,44$, and 60$)$ of parboiled and raw rice was taken in different conical flasks and $100 \mathrm{ml}$ distilled water was added in each of the flasks. Then the conical flasks were placed in an autoclave and autoclaved at 15 psig for 30 minutes. After that, $40 \mathrm{ml} 6(\mathrm{~N})$ $\mathrm{HCl}$ was added in each flask and inversion was carried out at $67^{\circ} \mathrm{C}$ for 20,30 and 45 minutes and after inversion, neutralization of $\mathrm{pH}$ of the hydrolyzed mass was done by sodium hydroxide solution $(40 \% \mathrm{w} / \mathrm{v})$ and then volume was make up to $200 \mathrm{ml}$ in each flask. Then the samples were taken for assay of malto-dextrin.

\subsubsection{Separation of Proteins and Production of Malto-Dextrin}

Rice protein consists of four fractions with different solvent solubility: albumin (water-soluble), globulin (salt soluble), glutelin (alkali-soluble), and prolamin (alcohol-soluble). Globulin (about 12\%) and glutelin (about 80\%) are the two major proteins, and albumin (about $5 \%$ ) and prolamin (about $3 \%$ ) are minor ones [6].

Rice proteins were separated from defatted 18 mesh parboiled rice flour according to the method described by Z.Y. JU et al., 2001 [6]

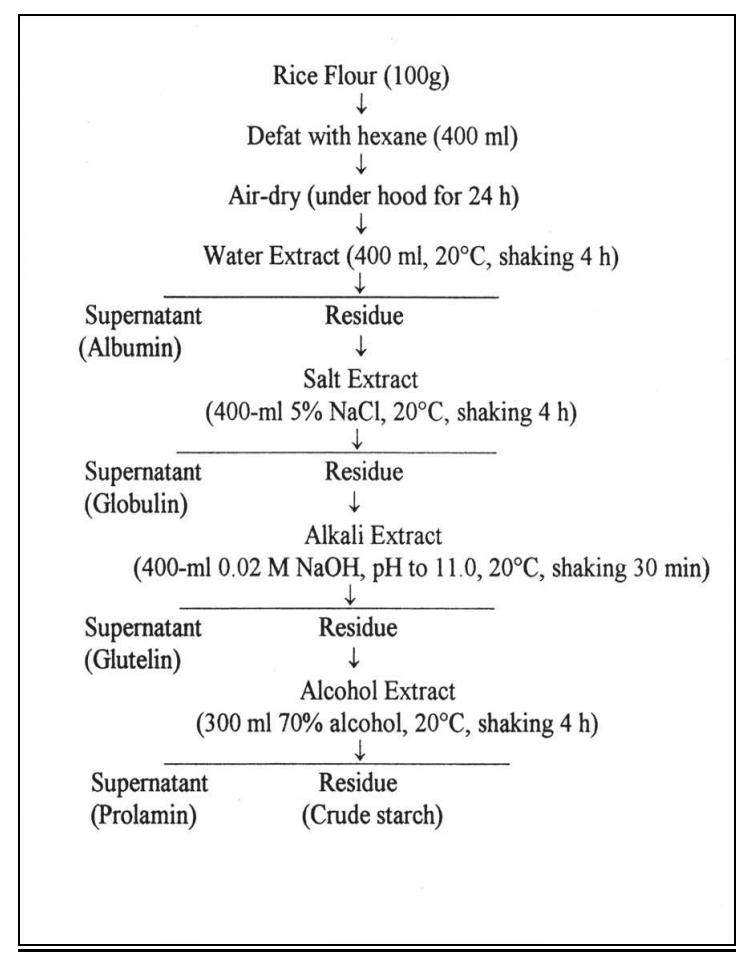

Proteins separation flow sheet

Malto-dextrin was produced from protein separated rice flour by gelatinization at $15 \mathrm{psig}$ for 30 minutes and saccharification for 30 minutes at $67^{\circ} \mathrm{C}$ by $6(\mathrm{~N}) \mathrm{HCl}$.

\subsubsection{Assay Method of Malto-Dextrin (Reducing Sugar)}

\subsubsection{Dextrose Equivalent Titration Method}

\section{Materials:}

- $\quad$ Standard dextrose solution: $(2 \mathrm{mg} / \mathrm{ml})$

- Fehling reagent: (Fehling A \& Fehling B solution)

- Methylene blue 


\section{Method:}

- $\quad$ Pipetted out $1 \mathrm{ml}$ of Fehling A and $1 \mathrm{ml}$ of Fehling B in a conical flask.

- Heated the solution until to boil.

- Titrated against standard dextrose solution until break red colour developed using methylene blue as indicator till the brick-red colour developed and burette reading was recorded.

Again the first two steps were followed for different samples for determination of reducing sugar and titrated against different samples and burette reading was recorded.

\section{Calculation:}

$\%$ of reducing sugar (per $100 \mathrm{gm}$ of rice flour) $=[\{$ (burette reading for standard titration*2)/burette reading for sample titration $\}^{*}$ volume of content in conical flask*100]/weight of sample taken.

\subsubsection{Dinitrosalicylic Acid Method [5]}

\section{Materials:}

- Dinitrosalicylic acid reagent (DNS reagents): Dissolved by stirring $1 \mathrm{gm}$ dinitrosalisylic acid, $200 \mathrm{mg}$ crystalline phenol and $50 \mathrm{mg}$ sodium sulphite in $100 \mathrm{ml} 1 \% \mathrm{NaOH}$ and Stored at $4^{0} \mathrm{C}$.

- $40 \%$ Rochelle salt solution (potassium sodium tartrate)

- Standard solution of dextrose $(2 \mathrm{mg} / \mathrm{ml})$

\section{Method:}

- $\quad 0.2,0.4,0.6,0.8,1 \mathrm{ml}$ of the standard solution and $1 \mathrm{ml}$ of sample solution was pipetted out in different test tubes and $2 \mathrm{~mL}$ of DNS reagent was added in each of the test tube.

- The content was heated in a boiling water bath for 5 minutes.

- $1 \mathrm{ml}$ of $40 \%$ Rochelle salt solution was added to each of the test tubes while the contents were still warm.

- The test tubes were brought down to room temperature.

- After cool, the volume was made up to $11 \mathrm{ml}$ in each of the test tube.

- The absorbance of the cooled content dark red solution at $560 \mathrm{~nm}$ was taken by spectrophotometer (Manufactured by-Systronic, Model no.-2202).

- Standard curve was prepared with 0-2 mg dextrose solutions absorbance (Fig-6).

\section{Calculation:}

From the standard graph equation by putting the value of absorbance of sample reducing sugar percentage was determined.

\section{RESULT AND DISCUSSIONS}

\subsection{Proximate composition of raw and parboiled rice}

Table 1: Proximate composition of raw and parboiled rice

\begin{tabular}{|c|c|c|c|c|}
\hline Parameters & \multicolumn{2}{|c|}{ Raw rice (\%) } & \multicolumn{2}{c|}{$\begin{array}{c}\text { Parboiled rice } \\
(\%)\end{array}$} \\
\hline & $\begin{array}{c}\text { Wet } \\
\text { basis }\end{array}$ & $\begin{array}{c}\text { Dry } \\
\text { basis }\end{array}$ & $\begin{array}{c}\text { Wet } \\
\text { basis }\end{array}$ & $\begin{array}{c}\text { Dry } \\
\text { basis }\end{array}$ \\
\hline Moisture & 13.38 & - & 10.78 & - \\
\hline Ash & 0.98 & 1.12 & 2.02 & 2.26 \\
\hline Protein & 5.64 & 6.51 & 5.05 & 5.66 \\
\hline Fat & 1.02 & 1.18 & 1.12 & 1.25 \\
\hline
\end{tabular}

Parboiled rice contains gelatinized starch and releases certain amount of moisture during processing (boiling). So, moisture content of parboiled rice is less than raw rice and hence percentages of protein, fat, ash content are also higher in parboiled rice. Ash content of rice depends on the bran present in it, which is not dependent on boiling of paddy. Amylose content of parboiled rice was determined from the standard graph (Fig1). Figure 1: shows that amylose content is $37.34 \%$.

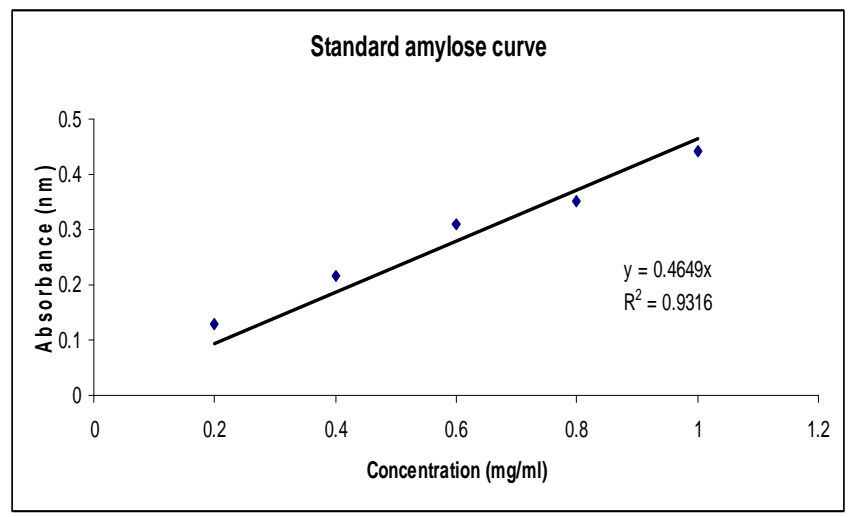

Fig 1: Standard curve of Amylose.

\subsection{Optimization of Particle Size}

Different rice flour, both raw and parboiled, was taken for gelatinization and saccharification under a specific condition. After saccharification the reducing sugar was measured and flour with particle size 18 mesh shown maximum productivity $72.98 \%$ and $90.43 \%$ for raw and parboiled rice (Table: 2 ) respectively. Parboiled rice gets gelatinized previously so it its productivity is higher than raw rice.

\subsection{Optimization of Gelatinization Process}

The gelatinized process was carried out at different pressure and time, 10 psig and 15 psig. Gelatinization time was varied from 10 minutes to 45 minutes. From table: 2, it is shown that optimized condition is 15 psig and 30 minutes. 


\subsection{Optimization of Saccharification Process}

The saccharification process was carried out at $67^{\circ} \mathrm{C}$ for 20,30 and 45 minutes. The optimized condition was at $67^{\circ} \mathrm{C}$ for 30 minutes.

\subsection{Separation of Proteins from Rice}

The proteins were isolated from rice flour by above mentioned process. The total separated protein percentage from 18 mesh parboiled rice was $5.04 \%$ (wet basis).

\subsection{Percentage of malto-dextrin of raw and parboiled}

rice

Table 2: Percentage of malto-dextrin at different condition of gelatinization and Saccharification

\begin{tabular}{|c|c|c|c|c|}
\hline $\begin{array}{l}\text { Type } \\
\text { of } \\
\text { rice }\end{array}$ & $\begin{array}{c}\text { Gelatinization } \\
\text { condition }\end{array}$ & $\begin{array}{c}\text { Saccharificatio } \\
\text { n condition }\end{array}$ & $\begin{array}{l}\text { Mesh } \\
\text { size }\end{array}$ & $\begin{array}{c}\% \text { of } \\
\text { malto- } \\
\text { dextrin } \\
\text { (per } \\
100 \mathrm{gm} \\
\text { rice) }\end{array}$ \\
\hline \multirow{12}{*}{$\begin{array}{l}\text { Raw } \\
\text { Rice }\end{array}$} & \multirow{4}{*}{$\begin{array}{c}10 \text { psig } 10 \\
\text { minutes }\end{array}$} & \multirow{12}{*}{$\begin{array}{l}67^{\circ} \mathrm{C} \\
\text { 20minutes }\end{array}$} & 18 & 19.8 \\
\hline & & & 30 & 20.8 \\
\hline & & & 44 & 18.9 \\
\hline & & & 60 & 14.85 \\
\hline & \multirow{4}{*}{$\begin{array}{l}15 \text { psig } 30 \\
\text { minutes }\end{array}$} & & 18 & 69.33 \\
\hline & & & 30 & 59.42 \\
\hline & & & 44 & 46.22 \\
\hline & & & 60 & 41.6 \\
\hline & \multirow{4}{*}{$\begin{array}{l}15 \text { psig } 45 \\
\text { minutes }\end{array}$} & & 18 & 69.33 \\
\hline & & & 30 & 59.42 \\
\hline & & & 44 & 69.33 \\
\hline & & & 60 & 52 \\
\hline \multirow{6}{*}{$\begin{array}{l}\text { Raw } \\
\text { rice }\end{array}$} & \multirow{6}{*}{$\begin{array}{l}15 \text { psig } 30 \\
\text { minutes }\end{array}$} & \multirow{4}{*}{$\begin{array}{l}67^{\circ} \text { c } 30 \\
\text { minutes }\end{array}$} & 18 & 71.72 \\
\hline & & & 30 & 61.17 \\
\hline & & & 44 & 70.51 \\
\hline & & & 60 & 53.35 \\
\hline & & \multirow{2}{*}{$\begin{array}{l}67^{\circ} \mathrm{c} 45 \\
\text { minutes }\end{array}$} & 18 & 72.98 \\
\hline & & & 30 & 61.17 \\
\hline
\end{tabular}

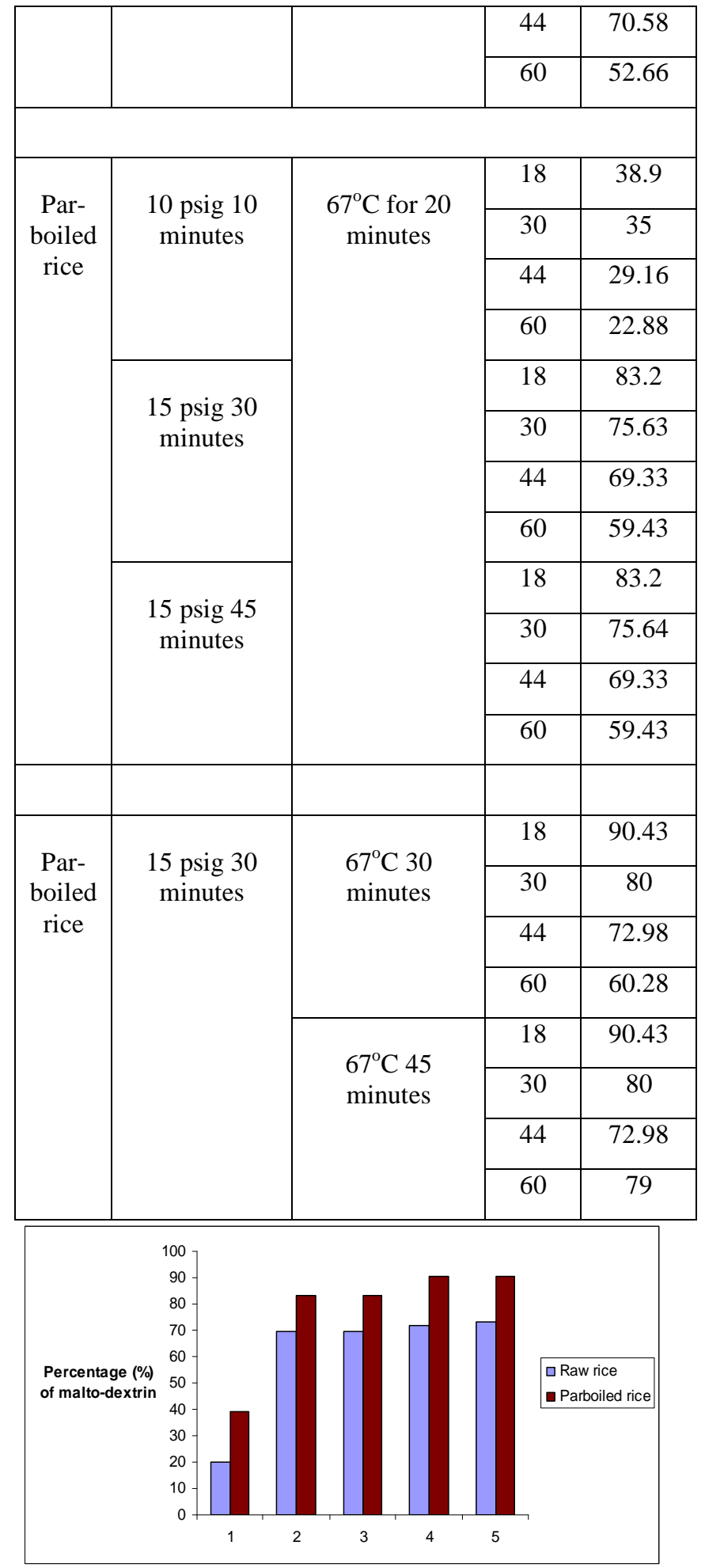

Fig 2: Reducing sugar percentage of 18 mesh size Raw and Parboiled rice at different gelatinization and saccharification condition. 
The numbers 1, 2, 3, 4 and 5 of Fig-2 denotes the following 1 - Gelatinization at 10psig for 10 minutes and saccharification at $67^{\circ} \mathrm{Cfor} 20$ minutes.

2- Gelatinization at 15 psig for 30 minutes and saccharification at $67^{\circ} \mathrm{C}$ for 20 minutes.

3- Gelatinization at $15 \mathrm{psig}$ for 45 minutes and saccharification at $67^{\circ} \mathrm{C}$ for 20 minutes.

4- Gelatinization at $15 \mathrm{psig}$ for 30 minutes and saccharification at $67^{\circ} \mathrm{C}$ for 30 minutes.

5- Gelatinization at $15 \mathrm{psig}$ for 30 minutes and saccharification at $67^{\circ} \mathrm{C}$ for 45 minutes.

From figure 2 it is clear that the best yield of malto-dextrin percentage of raw and parboiled rice i.e. $72.98 \%$ and $90.43 \%$ respectively is obtained at gelatinization condition of $15 \mathrm{psig}$ for 30 minutes and saccharification condition of $67^{\circ} \mathrm{C}$ for 30 and 45 minutes, as time duration gap of saccharification condition (i.e. 30 and 45 minutes) has no effect on rice starch means there is no enhancement in malto-dextrin percentage. Hence it can be concluded that the optimized gelatinization and saccharification condition for 18 mesh size raw and parboiled rice is $15 \mathrm{psig}$ for 30 minutes and $67^{\circ} \mathrm{C}$ for 30 minutes respectively. It is also noticeable that the percentage yield of reducing sugar of parboiled rice is higher than raw rice at different conditions of gelatinization and saccharification.

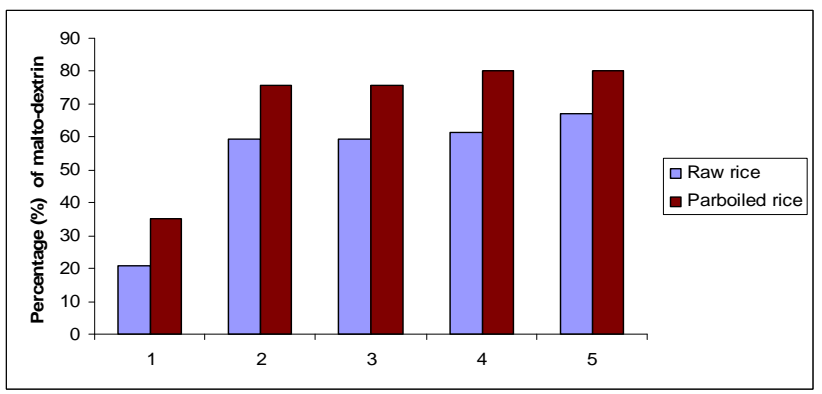

Fig 3: Reducing sugar percentage of 30 mesh size Raw and Parboiled rice at different gelatinization and saccharification condition.

The numbers 1, 2, 3, 4 and 5 in Fig 3 have the same connotations as in Fig 2.

From Figure 3 it is clear that the best yield of malto-dextrin percentage of raw and parboiled rice i.e. $70.51 \%$ and $72.98 \%$ respectively is obtained at gelatinization condition of $15 \mathrm{psig}$ for 30 minutes and saccharification condition of $67^{\circ} \mathrm{C}$ for 30 and 45 minutes, as time duration gap of saccharification condition (i.e. 30 and 45 minutes) has no effect on parboiled rice starch rice starch means there is no enhancement in maltodextrin percentage but in case of raw rice there is an enhancement of $0.07 \%$ which is negligible. Hence it can be concluded that the optimized gelatinization and saccharification condition for 30 mesh size raw and parboiled rice is $15 \mathrm{psig}$ for 30 minutes and $67^{\circ} \mathrm{C}$ for 30 minutes respectively. It is also noticeable that the percentage yield of reducing sugar of parboiled rice is higher than raw rice at different conditions of gelatinization and saccharification.

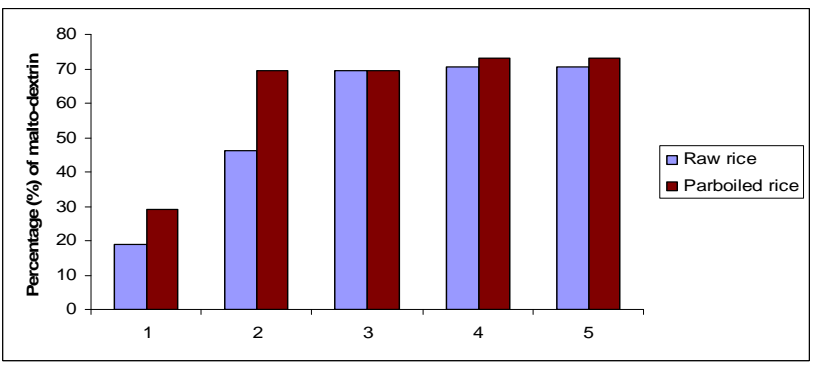

Fig 4: Reducing sugar percentage of 44 mesh size Raw and Parboiled rice at different gelatinization and saccharification condition.

The numbers 1, 2, 3, 4 and 5 in Fig 4 have the same connotations as in Fig 2.

From figure 4 it is clear that the best yield of malto-dextrin percentage of raw and parboiled rice i.e. $67.17 \%$ and $80 \%$ respectively is obtained at gelatinization condition of $15 \mathrm{psig}$ for 30 minutes and saccharification condition of $67^{\circ} \mathrm{C}$ for 30 and 45 minutes, as time duration gap of saccharification condition (i.e. 30 and 45 minutes) has no effect on rice starch means there is no enhancement in malto-dextrin percentage. Hence it can be concluded that the optimized gelatinization and saccharification condition for 44 mesh size raw and parboiled rice is $15 \mathrm{psig}$ for 30 minutes and $67^{\circ} \mathrm{C}$ for 30 minutes respectively. It is also noticeable that the percentage yield of reducing sugar of parboiled rice is higher than raw rice at different conditions of gelatinization and saccharification except gelatinization and saccharification condition of $15 \mathrm{psig}$ for 45 minutes and $67^{\circ} \mathrm{C}$ for 20 minutes respectively.

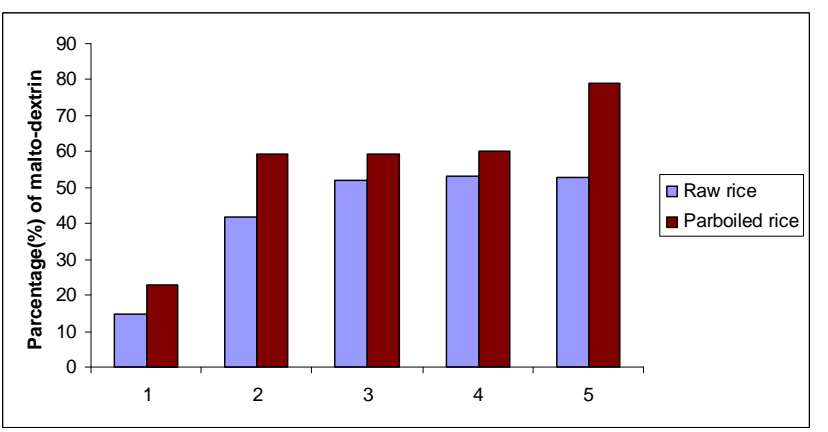

Fig 5: Reducing sugar percentage of 60 mesh size Raw and Parboiled rice at different gelatinization and saccharification condition 
The numbers 1, 2, 3, 4 and 5 in Fig 5 have the same connotations as in Fig 2.

From figure 5 it is clear that the best yield of malto-dextrin percentage of raw and parboiled rice i.e. $53.35 \%$ and $79 \%$ respectively is obtained at gelatinization condition of $15 \mathrm{psig}$ for 30 minutes and saccharification condition of $67^{\circ} \mathrm{C}$ for 30 and 45 minutes, as time duration gap of saccharification condition (i.e. 30 and 45 minutes) has no effect on rice starch rice starch means there is no enhancement in malto-dextrin percentage. Hence it can be concluded that the optimized gelatinization and saccharification condition for 60 mesh size raw and parboiled rice is 15 psig for 30 minutes and $67^{\circ} \mathrm{C}$ for30 minutes respectively. It is also noticeable that the percentage yield of reducing sugar of parboiled rice is higher than raw rice at different condition of gelatinization and saccharification.

\subsection{Percentage of malto-dextrin by Dinitrosalicylic}

\section{acid method}

From the data of table: 2, the optimized particle size was 18 mesh parboiled rice. So, Dinitrosalicylic acid method was performed only with optimized particle size and type of rice that was gelatinized and saccharified at optimized condition.

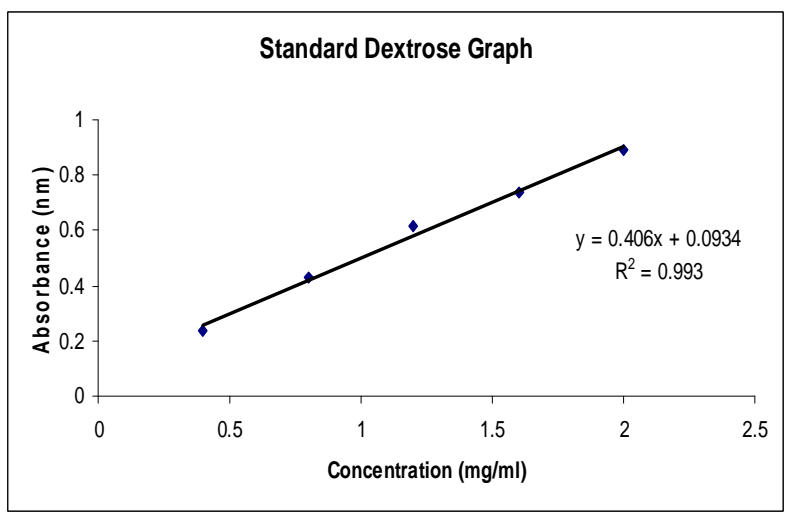

Fig 6: Standard dextrose curve

From the above standard Dextrose curve the calculated value of malto-dextrin is $88.63 \%$.

\subsection{Percentage of malto-dextrin from protein}

\section{separated rice particle}

Protein was separated from 18 mesh parboiled rice as it was providing the best yield of malto-dextrin at optimized gelatinization and saccharification condition. Yield of maltodextrin from protein separated rice particle was $94.43 \%$.

\section{CONCLUSIONS}

An experimental study of malto-dextrin production from different raw and parboiled broken rice particle under different experimental conditions was performed. The influence of fat and protein separation from optimized rice particle was also studied. The results have shown that particle size and type of rice has an effect on malto-dextrin production. The particle size may affect the leaching out of amylose content and thus break down of $\alpha$ $(1 \rightarrow 4)$ and $\alpha(1 \rightarrow 6)$ linkage also affect.

The optimized particle size and type of rice was 18 mesh parboiled rice. Best gelatinization and saccharification was 15 psig for 30 minutes and $67^{\circ} \mathrm{C}$ for 30 minutes. The highest yield was $90.43 \%$. For fat and protein separated particle there was about $4 \%$ increase in malto-dextrin production. The percentage of malto-dextrin is high and the optimized process parameters can be used for an industrial production purpose after pilot plant trial.

\section{ACKNOWLEDGEMENTS}

Authors gratefully acknowledge TIFAC-CORE for financial supports \& Techno India for infrastructural facilities.

\section{REFERENCES}

[1]. Alexander, J.R., (1992). Maltodextrins; production, properties and applications in starch hydrolysis products Schenck EW, Hebeda RE, Eds., VCH,New York.

[2]. Storz,E. and steffens, K. (2004). feasibility study for determination of the dextrose equivalent (DE) of starch hydrolysis product with near-infrared spectroscopy (NIRS). Starch. 56(2): 58-62.

[3]. A.M. Donald, P.A. Perry and T.A. Waigh, (1999). Fibre diffraction review, 8: 31-37.

[4]. T.Suzuki, A. Chiba and T. Yano, (1997). Carbohydate Polymers, 34:357-363.

[5]. Sadasivam, S. \& Manickam, A (2005). Biochemical Methods. New Age International Publishers, 2nd edition, p.12. [6]. Z.Y. JU, N.S. HETTIARACHCHY, N. RATH 2001 Extraction, Denaturation and Hydrophobic Properties of Rice Flour Proteins, JOURNAL OF FOOD SCIENCE. Vol. 66, No. 2. 